\title{
Students' Perception Regarding the Teaching Strategies of Government ESL School Teachers and Private Tutors: With Special Reference to a Grade Nine Government School in Galle, Sri Lanka
}

Sri Lanka Journal of Social Sciences and Humanities Volume 1 Issue 1, February 2021: 63-70 ISSN: 2773 692X (Online), 27736911 (Print) Copyright: (C) 2021 The Author(s)

Published by Faculty of Social Sciences and Languages, Sabaragamuwa University of Sri Lanka Website: https://www.sab.ac.lk/sljssh

\author{
Gurusinghe, S.A. ${ }^{1,{ }^{*}}$ and Ramanayake, I.S. ${ }^{2}$ \\ ${ }^{1}$ Faculty of Management and Finance, University of Ruhuna, Matara, 81000, Sri Lanka. \\ 2 Department of English Language Teaching, Faculty of Humanities, University of Kelaniya, 11600, Sri Lanka.
}

Received: 10 November, 2020, Revised: 24 December, 2020, Accepted: 20 February, 2021.

How to Cite this Article: Gurusinghe, S.A., \& Ramanayake, I.S. (2021). Students' perception regarding the teaching strategies of government ESL school teachers and private tutors: With special reference to a grade nine government school in Galle, Sri Lanka. Sri Lanka Journal of Social Sciences and Humanities, 1(1), 63-70.

\begin{abstract}
Today, the English language has drawn 'global recognition' and is taught as the second language in most of the countries around the world. In Sri Lanka too, there is a considerable demand for learning English as a second language. English is being taught as a Second Language in government schools as well as in private institutes in Sri Lanka. However, the role of the teacher undergoes fundamental changes with the delivery of a multidimensional second-language program. It is the teacher who acts as a facilitator, resource person, and language model for the second-language classroom. Thus, this study examines the perception of the students regarding the teaching strategies used by government ESL school teachers and private tutors. The study was based on a mixed approach with a survey and a questionnaire. A mixed school in Galle District, Sri Lanka was used as the study area including one hundred and seventy-two students of grade nine using the justification sampling method. The interview was conducted considering the random sampling method with ten students. However, perception varies according to the attitudes of the students regarding the teaching strategies used by the teacher. According to statistical information, it is evident that a large number of students prefer private tutoring as an aid to their government school education in ESL learning. Therefore, the implementation of new strategies is discovered to be important to serve every student in a common ground. Motivational factors are of greater importance in enhancing the ESL knowledge of the students and making them competent in the acquisition of the language.
\end{abstract}

Keywords: ESL learning, Grade nine, Private tuition, School education, Student perception, Teaching strategies

\section{INTRODUCTION}

The history of English language runs back to the 5th century A.D and it begins with the arrival of three Germanic tribes. They were the Angles, Saxons, and Jutes. The Angles came from "Englaland" and their language was called "Englisc" from which the words "England" and "English" are derived. In contemporary society, English has become the lingua franca almost in most countries. According to statistics nearly half of the population use this language even to a certain degree. Many people believe that the English language would bring extinction to the local cultures, but it is completely the opposite and many people believe in that language. They are in the need to learn the language in order to have a good reputation and to be on the top ranks in society. The English language is a dire necessity to everyone, and it is being felt throughout the world. The English Language was introduced to Sri Lanka by the British in 1798. Even after 71 years after gaining independence in 1948, still English language remains to be a status symbol in Sri Lanka. English language being the language of science, computer technology, aviation, and diplomacy, the necessity of mastering the language has become an essential need. This is evident in the contemporary context where a boost of the number of English classes conducted by people with various qualifications is notable. At the same time, the parents who believe that private tutors do much better in classes than in the school environment are also keen to send their children to private tutors apart from their school ESL teacher. The government has also taken many steps in order to enhance both the productive and receptive skills of the school children. Distribution of English textbooks and producing qualified ESL teachers with the knowledge of innovative teaching strategies are a few of many considerable measures that were taken by the government. In such a circumstance, the government ESL teachers who are well trained by conducting many teacher training programs are convinced to have private classes not only for the students of other schools but also for the ones who are under their guidance at schools. In that case, the problem, why these students prefer to go to private classes of the same teacher rises. Thus, this study focuses on the student's perception regarding the teaching strategies used at school and private classes by the ESL teachers, how they differ from one another. Moreover, it also investigates in which way these effective strategies can be utilized in order to amplify the English language skills of ESL learners. 
The teacher-student relationship is the basic fundamental in evaluating the learner outcomes. It is necessary to have a two-way interaction in order to develop a good learner healthy background. Learning a language is an active process, both the teacher and the learner should actively take part in the process of teaching and learning. McDonough (1986) puts it clearly that "as language teachers, we need to understand as much as possible about the language teaching/ language learning process." It is doubtless that teachers have a powerful role in L2 learning. A traditional classroom is teacher-centered but in recent times the classroom is more student-centered. The teacher should be mindful of the students' participation in an ESL classroom because a language can only be learned through active participation. Therefore, students' perception of the teaching strategies needs to be taken into consideration. There is a noticeable change in students' perception of their school teacher and private tutor. In contemporary society, students tend to attend private tutors apart from their school ESL teacher as a matter of various perceptions that students have. Therefore, this study which investigates the students' perception regarding the teaching strategies of government ESL school teacher and the private tutor and how it affects the ESL learning of the students is important as it will contribute to implementing new strategies in government schools in order to enhance English Language skills of the ESL learners.

It is evident that a limited number of research articles are published on different aspects of ESL teaching and this study investigates the students' perception regarding the teaching strategies of government school ESL teacher and the private tutor, is not an area that has been researched or addressed up to date.

\section{LITERATURE REVIEW}

The decisions made by the ESL teacher in the classroom are highly important in the process of teaching and learning. In the traditional classroom, context teachers were playing a dominant role and the class was structured in the form of a lock step classroom. All activities are "teacher-fronted" and in the current context students are active learners and teachers are facilitators. They play a passive role in the classroom. Students play a vital role in the class structure. As stated by Addisu Sewbihon Getie and Maria Popescu the perception of students regarding their ESL teacher can have a positive or negative effect upon their learning. Teaching a language requires an ample amount of effort in relation to many skills, teaching methodology, right decision making at the proper time, and evaluation. It's an art that has to be mastered to create the future of the world.

There are various environments in which students learn ESL. School is the basic and most fundamental place where the students receive proper education apart from the help of their parents at home. Private tutoring is the next step that most of the students tend to take in their learning process. Private tutoring is at a stage where it's difficult to decide whether it's a supplement for a school education or merely a trend that students follow. The teaching strategies vary from person to person and also from one institute to the other. These varying strategies lead to the change of student's perception towards government ESL teachers and private tutors.

ESL education for Government schools and private tutoring: Government school education has been recognized as the main mode through which society educates their younger generations. Government school education is considered free education. Dr. C. W. W. Kannangara by making education free for all students benefitted thousands of underprivileged students in rural parts. The fast-moving world has introduced a new way of learning as private tuition. Private tutoring regarding ESL also has gone hand in hand in the past few decades and it has brought rapid growth adding a trend of gaining knowledge and skills. People who were engaged in agricultural activities and other household chores have felt the importance of learning. Moreover, the importance of learning English to cope up with the ongoing world is also evident. The necessity of learning English as the second language has opened avenues in various ways. Based on the findings of Samia Manzoor school students tend to gain more knowledge of English as their second language, by attending tuition classes.

In addition, it is clear that a few research had been administrated concerning students' perception regarding the teaching strategy. Therefore, the necessity to have a close observation on "students' perception regarding the teaching strategy of government ESL school teacher and the private tutor" drew the attention of the researcher. The main reason for implementing this research is that a study of this nature hasn't been implemented at any level or forum to date though it has become a necessity. Therefore, the research gap is defined and subjected to be researched in terms of exploring the feasibility of the application.

Student's perception in language learning: Dr. Tūrkay BULUT and Selma DURAK UGUTEN performed a study aiming at the comparison between students and their teacher's perception about English Language teaching activities. According to him, learners have the right to decide what to learn, when, and why to learn. A contrasting idea was presented by Barkhuizen (1998), "learners are ignored or seldom involved during this decision-making process".

The above-given idea regarding the teacher and the students' language learning is important. The teacher as well as the student must receive equal importance in the classroom. Therefore, students have the right to decide on their learning materials to achieve the maximum benefit of learning the language. Ignoring the learner might lead to negative attitudes and it will affect the language acquisition of the student.

As Fermon stated (1998) that "seeing teaching as choosing options or making decisions is not by itself new or controversial". The students should be given the freedom to select and to learn and the teacher's role is to facilitate the learners whenever it is needed.

As Lewis and Hill stated: "it is almost invariably a good idea to begin a new course by discussing with students why they are studying English, what uses they see for the English they learn, and something for their expectations of what they expect to happen in the classroom... (1990, p.9). It is evident that both these researchers have stated that student's perception is really important in the ESL learning and teaching process.

Mc. Donough (1986) has stated that "as language teachers, we need to understand as much as possible about the language teaching/ language learning process" (p. 161). It is clear that teachers should always be mindful, and the teacher must learn various teaching methods to create a learner-friendly environment that makes the learner effectively learn ESL. The main reason for considering learner per- 
ception in teaching is because without learner's participation in an ESL classroom the teacher too won't have an active and enjoyable classroom.

According to the standpoint of Bada (1997), "student-centered approaches are those where learners are no longer free from the responsibility of contributing to the language learning; rather they are active participants in designing and evaluating their language learning process" (p.20). Teachers creating a student-centered classroom can have a positive perception regarding the ESL teacher. The teaching strategies used by the teachers can be very effective as well as not at all effective depending on the perception of the students towards their teacher

The study of "The importance of student perception in language teaching" has mainly focused on the ESL teaching activities and they have concluded the perception of the in structors did not always match with those of the students and also the students preferred to have more communicative activities rather than doing reading aloud by the teacher.

Shengli ZHAN, Mark BRAY, Don WANG, Chod LYKINS, and Ora KWO have surveyed regarding "The effectiveness of private tutoring: students' perception in comparison with mainstream schooling in Hong Kong." According to their opinion "students generally perceive private tutoring and private tutors to be more effective in the provision of examination support 7 compared with the mainstream schooling in Hong Kong." It also states that private tutoring is received to academic subjects as a supplement to the mainstream schooling system. They have made a comparative study to analyse the perception of students about school education and private tutoring in Hong Kong.

The above quotation reveals that private tuition is more important to get through examinations. Marimuthu et al (1991: v1) also states that private tuition as "shadow education" private tutoring is presented as a helping aid to mainstream school education. Bary too relates the appropriateness of the above-mentioned question depicting that supplementary tutoring only exists because of the existence of mainstream education, the changes that occur in mainstream also occur in supplementary tutoring and that he used to elicit the appropriateness of denoting tuition as "shadow education". Almost all societies pay more attention to the mainstream than shadow education. The features of the shadowed stream are less distinguishable than those of the mainstream.

Dawson too has used a biological metaphor in describing private tutoring as "parasitic" and Baker and LeTendre 2005, Mori and Baker 2010 described the relationship as "symbiotic". Although there are various metaphors to describe private tuition all these metaphors share comparisons and all the metaphors carry the idea of supplementary education.

The findings of this study have depicted that English and Mathematics were the most popular subjects for tutoring. According to the statistics, $70 \%$ of students receive tutoring in English and nearly 60\% in Mathematics. The discovered data reveals that during exam periods students pay as much as fifty hours per week in private tutoring for many subjects (English, Mathematics, and Chinese) than the time they spend in mainstream classrooms.

The survey classified tutoring into various categories as oneon-one tutoring, small-group tutoring, lecture-type tutoring, and online tutoring. Out of these four types of tutoring oneon-one tutoring and small-group tutoring are more effec- tive. The effectiveness of these tutoring is witnessed in improving examination grades, confidence in examinations, revision skills, and learning strategies.

Importance of private tutoring: The data reveals that there is a necessity for private tutoring and going for private tuition has increased from grade nine to twelve as they feel the necessity to cope with their subjects and to increase their results as they are in their secondary schools.

It is evident through the survey that the perception of the parents also matters in selecting private tutoring. The general acceptance of the society leads parents to march forward with private tutoring as a trend and also for educational purposes.

The paper published by Shengli ZHAN, Mark BARY, Dan WANG, Chad LYKINS, and Ora KWO concludes that Hong Kong secondary students have great demand for private tutoring. The data revealed that "examinations and the consequences from success or failure in examinations were the dominant drivers of demand for tutoring". The study has drawn a comparison between teachers and tutors in a common ground where all the subjects needed to be catered with tutoring.

According to the above-mentioned article, it is clear that private tuition is important but they haven't discussed the reasons for the students to attend private tutoring to develop their ESL knowledge. Moreover, they have given an overall idea by doing a comparative study of the perception of the students about their mainstream teachers and private tutors. In addition, the effects of students' attitudinal change, towards the strategies used by the school ESL teacher and private tutor is not addressed in the above-mentioned study.

The concept of extra tuition is a practice that is said to enrich the academic ability of learners with the hope of sharpening their preparedness for the natural examinations (Wanyama and Njeru, 2003). According to the above quotation, extra tuition was conducted to develop the learner knowledge and tutoring is a common phenomenon since the 1960s in several parts of East Asia especially in Japan, the Republic of Korea, and Taiwan (Hallack and Paison, 2007), Hallack and Poison (2007) has also observed that extra tutoring was given to children of 3 years of age in Australia. Tutoring in Australia is common and there is also a method of funding private tutoring. According to Bray, one-third of the students in Egypt receives private extra tuition.

According to the above quotations, it is evident that private tutoring is a part and parcel of the education system. Therefore, according to this article, "Teachers and students' perception on effect of extra tuition on academic performances in public secondary schools in Machakos County, Kenya" reveals that most teachers $(85 \%)$ and students (82\%) supported the practice of extra tuition. Through the data analysis, it was concluded that extra tuition helps students to cover the syllabus and revise for examinations. "Based on findings of the study, it was concluded that extra tuition is a common practice in secondary schools in Machakos county". (Maithya and Mutua, 2015)

The study, "Perception of parents on the practice of private tuition in public learning institutions in Kenya" had discovered that parents had a positive, favorable attitude towards private tuition.

Moreover, Stevenson and Baker (1992) refer to private tutoring as a set of educational activities outside formal schooling that are administrated to improve student's ability to move easily through school education. 
According to the above statement, it is evident that the purpose of private tutoring is to improve the knowledge and skills of the students and to make them competent in education.

Tansel and Bircon (2006) define private tutoring as educational outside the formal schooling system where the tutors teach particular subjects for financial gain.

The justification provided by Tansel and Bircon provides evidence to the fact that for tuition there are other ulterior motives as well.

Finally, it is distinctively evident that it is important to investigate the student's perception regarding the teaching approach of government ESL school teachers and private tutors. Moreover, this study must be conducted based on grade nine government school students who are in their adolescence.

\section{RESEARCH METHODOLOGY}

Introduction: This study adopted a descriptive research design to investigate the students' perception regarding the teaching strategies of government ESL school teachers and private tutors and this study was conducted based on a grade nine government school in Galle District in Sri Lanka. The study reported in this paper used mixed methods of both quantitative survey and qualitative interview. Creswell and Plano Clark (2007) highlighted several types of mixed research methods. A common approach, used in this study, uses a qualitative survey to identify overall patterns and interview data to triangulate and illustrate these patterns. This paper is mainly based on the questionnaire and interviews which were held to have a deeper understanding to derive sensitive factors regarding the perception of students.

Sample: The qualitative data reported in this paper were driven through the non-probability sampling method. It was through judgmental sampling. Students in grade nine in a particular school in the Galle District were targeted. The rationale behind the sample of grade nine students is that their mindset is focused on studies and they are not exam oriented but in need of quenching their thirst for knowledge. Therefore, the researcher was compelled to have the sample set of students from grade nine. Table 1 denotes the sample as one hundred and seventy students out of a population of eighty-six thousand students. The questionnaire was distributed to all the students in grade nine in that particular school. According to census reports, there are 430 schools in Galle District including 6 boys' schools, 10 girls' schools, and 414 mixed schools. The selected school is one out of the top three mixed schools in Galle District with the lowest percentage of the failures in English for G.C.E O/L. The selected school represents both genders and an English medium class coming from grade one. The prime objective to focus on government school children is to derive a comprehensive perception of private tutors and ESL teachers. It is since an individual who has experienced both parties is highly productive as he or she compares and contrasts the two teachers based on his or her personal opinion. Therefore, the researcher was compelled to select this school.

Table 1: Sample

\begin{tabular}{lrr}
\hline Category & Sample & Population \\
\hline Students & 172 & 86000
\end{tabular}

Source: Survey data, 2020.

Instrumentation: Two tasks were utilized to gather data. Both quantitative and qualitative methods were used for data gathering and closed group interviews were done to gather sensitive data as a way to gather qualitative data.

The questionnaire was based upon fixed alternative questions. This method is also known as the closed type of questions and the students were provided with a Likert scale. The questions were categorized under three main categories as sections $A, B$, and $C$.

Section A contained personal questions about students' grades, sex, ethnicity, and the parent's occupation. Section $B$ contained two questions to have the general idea regarding the importance of private tuition and attendance to private tuition and section $C$ contained thirty-two questions based on several categories such as teacher personality, the language of the teacher, methodology, sensitivity, learning environment, and facilities and those categories were not mentioned in the questionnaire in order to gather authentic details from the students rather than having a biased attitude.

The questions related to these categories were divided into school and tuition. It was done to derive a comprehensive perception of private tutors and ESL teachers. Visiting tuition classes and filling up the questionnaire is not practical. The data can be affected by various reasons. This method of collecting data is very effective as an individual who has experienced both parties can easily compare and contrast the two teachers based on his or her personal experiences. A sample set of one hundred and seventy-two students are given a questionnaire as students experience their ESL teacher daily and thus may be an important source of information regarding the student's perception of their teachers' teaching process. Furthermore, students have experienced various teacher behaviours concerning teacher pleasantness, classroom language, and teaching methodology.

Then, closed group interviews were conducted to derive sensitive data and for this selection, a random sampling method was used. Two students from each class were randomly selected with the representative of both genders. Later on, ten questions were asked from each student. The beginning of the interview was quite informal discussion. Then the questions were asked to find the comparative and contrasting features of teaching approaches in government school ESL teachers and private tutors.

\section{DATA COLLECTION}

\section{First Level}

A sample questionnaire was given to a sample of twenty students to find out the effectiveness and to draw feedback from the students regarding the questions that were included. Classroom observation was also done while the students were filling it. The classroom observation was done to identify the level of the students. The feedback received by the researcher was neutral therefore, certain questions were included in the final questionnaire and some were omitted.

\section{Second Level}

The questionnaire was administrated after requesting the ESL teacher to leave the classroom. It was done to derive authentic information from the students. The questions were given in English and for better understanding, translation of each question was read aloud to the class. The participants were requested to refrain from writing their identity in the questionnaire. While the questionnaire was being filled the students came up with several comments as to how the government ESL teacher and private tutor differ. The comments of the students were also noted by the researcher. A five- 
point Likert scale was presented as denoted in table 2 with five options with the relevant marks.

Table 2: Perspectives of ESL learners based on the questionnaire

\begin{tabular}{ccccc}
\hline 1 & 2 & 3 & 4 & 5 \\
\hline $\begin{array}{c}\text { Strongly } \\
\text { Agree }\end{array}$ & Agree & Neutral & Disagree & $\begin{array}{c}\text { Strongly } \\
\text { Disagree }\end{array}$ \\
\hline
\end{tabular}

Source: Survey data, 2020.

Third Level

Next, ten students were selected randomly representing two students from both genders from five classes. The comments and their thoughts regarding the varying teaching strategies were noted down.

Then, the data obtained from the questionnaire were entered into SPSS (Statistical Package for Social Sciences) and the closed group interview answers of the ten students were analysed using the thematic analysis method.

\section{RESULTS AND DISCUSSION}

This section analyses data to derive a comprehensive understanding of the focused areas of the research. Since the perception of the students towards their ESL teacher affect their language development.

Conceptual Framework: As noted in figure 1 the students' perception regarding the teachers' quality of delivery has been identified as the dependent variable with a range of independent variables. The following independent variables are taken into consideration to explore the relationship to have a better understanding.

Teacher personality, Language of the teacher, Methodology, Sensitivity, and Learning environment and Facilities

\section{Figure 1: Conceptual Framework}

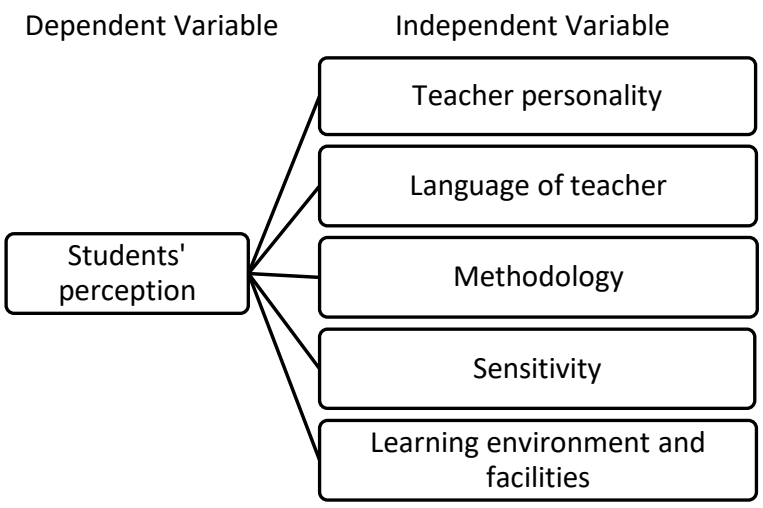

The researcher had to employ both qualitative and quantitative data to obtain a realistic perception of the focused area.

This segment is focused on statistical data analysis through SPSS (Statistical Package for the Social Sciences). The opinion of the students towards the teaching strategies of the government ESL teachers and private ESL tutors are analysed in this study.

The responses of the students towards these questionnaires and the informal interviews are considered as the main stakeholders and as the focal point. The included information is designed with graphs to create a visual impact on this comparative study. The data is categorized as follows with a view of analysing.

Student Questionnaire Data Analysis: This segment explains the responses of the main stakeholders who were subjected to the study. A questionnaire with 3 sections was utilized. The first section included questions about students' general information including their grade (Table 3 ), gender (Table 4), and ethnicity (Table 5). Section B included two selection questions. It analysed data on private tutoring. One was the importance of private tutoring (Table 6) and the other question focused on the participation of the students in private tutoring (Table 7). Section $\mathrm{C}$ included questions to have a clear study of the student's perception regarding government school ESL teacher and private tutor. Questions in section $C$ consisted of 32 questions and it was addressed under five main categories for better analysis.

Table 3: Grade

\begin{tabular}{ccccc}
\hline & Frequency & Percent & $\begin{array}{c}\text { Valid } \\
\text { Percent }\end{array}$ & $\begin{array}{c}\text { Cumu- } \\
\text { lative } \\
\text { Percent }\end{array}$ \\
\hline Valid 9 & 172 & 100.0 & 100.0 & 100.0
\end{tabular}

Source: Survey data, 2020.

Table 4: Gender

\begin{tabular}{cccccc}
\hline \multirow{2}{*}{ Valid } & & $\begin{array}{c}\text { Fre- } \\
\text { quen } \\
\text { cy }\end{array}$ & Percent & $\begin{array}{c}\text { Valid } \\
\text { Percent }\end{array}$ & $\begin{array}{c}\text { Cumu- } \\
\text { lative } \\
\text { Percent }\end{array}$ \\
\hline \multirow{3}{*}{ M } & $\mathrm{F}$ & 74 & 43.0 & 43.0 & 43.0 \\
\cline { 3 - 6 } & Total & 98 & 57.0 & 57.0 & 100.0 \\
\cline { 2 - 6 } & & 172 & 100.0 & 100.0 & \\
\hline
\end{tabular}

M=Male, F=Female

Source: Survey data, 2020.

Table 5: Ethnicity

\begin{tabular}{|c|c|c|c|c|c|}
\hline & & Frequency & Percent & $\begin{array}{c}\text { Valid } \\
\text { Percent }\end{array}$ & $\begin{array}{l}\text { Cumu- } \\
\text { lative } \\
\text { Percent }\end{array}$ \\
\hline Valid & $S$ & 172 & 100.0 & 100.0 & 100.0 \\
\hline
\end{tabular}

$S=$ Sinhala

Source: Survey data, 2020.

Table 6: Private Tuition

\begin{tabular}{|c|c|c|c|c|c|}
\hline & & $\begin{array}{c}\text { Fre- } \\
\text { quen } \\
\text { cy }\end{array}$ & Percent & $\begin{array}{l}\text { Valid } \\
\text { Percent }\end{array}$ & $\begin{array}{l}\text { Cumu- } \\
\text { lative } \\
\text { Percent }\end{array}$ \\
\hline \multirow{6}{*}{ Valid } & SA & 80 & 46.5 & 46.5 & 46.5 \\
\hline & A & 40 & 23.3 & 23.3 & 69.8 \\
\hline & $\mathrm{N}$ & 28 & 16.3 & 16.3 & 860. \\
\hline & D & 13 & 7.6 & 7.6 & 93.6 \\
\hline & SD & 11 & 6.4 & 6.4 & 100.0 \\
\hline & Total & 172 & 100.0 & 100.0 & \\
\hline
\end{tabular}

SA=Strongly Agree, $A=$ Agree, $N=$ neutral, $D=$ Disagree, $S D=S t r o n g l y$ Disagree

Source: Survey data, 2020.

Table 7: Attend to classes or Not

\begin{tabular}{cccccc}
\hline \multirow{2}{*}{ Valid } & & $\begin{array}{c}\text { Fre- } \\
\text { quen } \\
\text { cy }\end{array}$ & Percent & $\begin{array}{c}\text { Valid } \\
\text { Percent }\end{array}$ & $\begin{array}{c}\text { Cumu- } \\
\text { lative } \\
\text { Percent }\end{array}$ \\
\hline \multirow{3}{*}{\begin{tabular}{c} 
cy \\
\cline { 2 - 6 }
\end{tabular}} & $\mathrm{N}$ & 154 & 89.5 & 89.5 & 89.5 \\
\cline { 3 - 6 } & Total & 18 & 10.5 & 10.5 & 100.0 \\
\hline
\end{tabular}

$Y=Y e s, N=N o$

Source: Survey data, 2020. 


\section{Variable 1: Teacher Personality}

The first variable refers to the personality of the teacher. Four questions were directed to identify the contrasting perspective of the students regarding teacher personality in a government school and private tuition. The personality of the government school ESL teacher and private tutors was measured through the neatness, activeness, and having a beautiful or handsome personality.

\section{Variable 2: Language of the Teacher}

The second variable refers to the language used by the teacher. Five questions were given to identify the changing perspectives of students. It includes statements under the indicators of clarity of teacher instructions, ability to understand instructions easily, repetition of the lesson for better understanding, audibility of voice, and understandable nature of teacher language.

\section{Variable 3: Methodology}

The third variable refers to the methods or strategies used by the teachers. A comparative study is drawn to measure the perspectives of the students. It includes statements under the indicators of giving enough wait time to ask questions, use of different teaching methods, waits for majority

Figure 2: Dependent and independent variables understanding, special attention for weaker learners, activities such as group works, debates, speeches are conducted, covers the syllabus, readiness for lessons, giving homework, practice test to evaluate the level of the students, encouragement to learn the language, teacher availability, appreciation of the students, correcting the students and revising the learned lessons are the questions that were used. The majority were included under the variable as the study is based basically on the teaching approaches of the ESL teachers.

\section{Variable 4: Sensitivity}

The fourth variable addresses the sensitive behavior of the teacher towards students. Though learning is an active process it can depend on the sensitive nature of the teacher. It is analysed through the indicators of treating everyone alike, teacher cooperation with students, advising the students, and also helping the students whenever needed.

\section{Variable 5: Learning Environment and Facilities}

The last variable is the learning environment and the facilities available to the learners. It includes statements as, pleasant learning environment with necessary facilities, the use of technological resources, and providing extra tutorials related to the lessons.

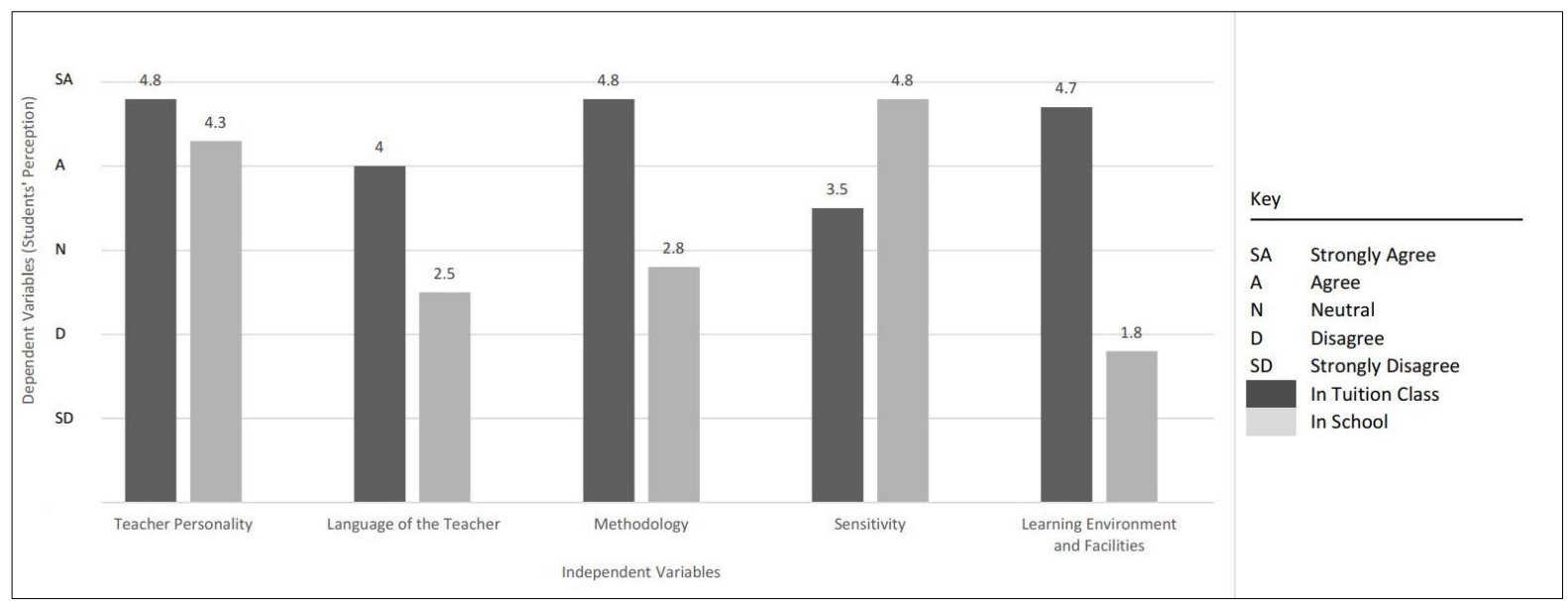

Source: Survey data, 2020.

The above mentioned five variables as presented in figure 2 give a descriptive analysis through a comparative study. The bar graphs denote that the students' perception towards the private tutor is positive. The sensitivity variable has a significant deviation in comparison to the other variables concerning school ESL education. Through that it is evident that the school ESL teacher is more sensitive and keen on the students than the private tutor. In the interviews, the students mentioned that the school teacher is closer and sensitive towards the students since the students are more familiar, as they spend more time in the school.

\section{Student Interview Data Analysis}

The questions on student's perception regarding the teaching strategies to teach ESL in both government schools and private tuition were addressed through informal interviews to derive sensitive data. The thematic analysis method was used to analyse the data. The interview questions focused on learning experiences in both schools and private tuition classes. The reasons for choosing private tutoring for assistant learning instead of finding help from school teachers.

In the process of informal interviews, the students were free to express their views and experiences about both govern- ment school ESL teacher and ESL tutor. During the interviews, the students discussed the key reason for seeking help through ESL tutors was the need to have better knowledge to gain more experience in using the language.

"I like to learn English, but in the school, I don't have the ability to identify my weaknesses and the school teacher wants us to finish one lesson per day and to cover up the syllabus. But in the class, the teacher makes the class more interactive and she puts extra classes for us."

The students stated that they lack the opportunity to use the language in the school context. The teaching strategies have compelled them to be more passive learners. They came up with the concept of treating front students the best, the most talented students the best. The selected students on a random basis talked with a note of disappointment while some students were delighted to talk about their ESL teacher. They stated that they lack chances to explore the world and did not receive opportunities to go for English day competitions due to the biased nature of the ESL teachers.

"I am going to my teacher's class and the teacher loves me a lot and she gives me chances to read the book in the class. The teacher takes me to the board and also I receive chances to go for English Day competitions" 
For the same question, another student replied in an opposite way.

"Teacher always asks answers from the students who go for her class. She marks their books first. She appreciates only those students and she always scolds me and punishes me. She never allows me to raise my voice. Even I and some of my friends don't get the opportunity to ask questions. She talks about those students who go to her class and she loves them a lot."

Based on the variables, the researcher was compelled to ask the same questions from the ten students. The overall attitude of the students regarding the variables was positive with ESL tutors and the sensitivity factor was negative. According to their opinion, the school ESL teacher is more familiar and closer towards the students.

The students' opinion was that private tutors use a lot of effort to teach English to the students. In order to achieve their objectives, the private tutors design their lesson plans with creative activities with the use of visual aids. Private tutors bring practical activities to the learner environment. Thereby, the students enjoy learning the language.

Two students objected to the idea from the rest of the students. They were on the standpoint that school education was better. According to their opinion, they stated that the education provided to ESL is sufficient in school to have good knowledge and also to achieve good grades.

"I like my school teacher she explains the lesson very well. She treats us all alike. She is like a mother to us."

The interviewed students who had positive attitudes towards private tutoring made explanations to the preference. They said that tutors were more inspiring, motivating, knowledgeable, supportive, and interactive with the students.

School ESL teachers are compelled to cover the syllabus and they are limited to the activities in the textbook and the students stated that although teachers label the classrooms as student-centered it is not the reality. All the decisions of the lessons and everything in the classroom are monitored by the teacher.

\section{CONCLUSION}

The analytical process, methodology, and techniques have instrumentalized the course of the study with close observations related to the dependent and independent variables in mechanizing a systematic progression. The specified condition based on identified objectives has directed the researcher to arrive at specific conclusions.

The objectives were to study the effects upon the learners and learning process due to the varying learner perceptions, determining the differences of learner perceptions towards government school teacher and private tutor in learning ESL, and also to examine the adolescents' psychological reactions to government and private ESL tutors.

The close observations through the questionnaire and the interviews have compelled the researcher to conclude that the number of students attending tuition classes is at a very high rate and the factors affecting this are mainly due to unchanging independent variables. Many students spend a whole lot of time at tuition classes than in schools. According to the analysed data, it is evident that the school ESL teachers lack motivational factors that help the students with their language acquisition and in comparison, the private tutor acts as the driving force that encourages and helps them in learning difficulties and acts as a creative mentor. He or she leads the learners to a world of practicality, and it has made the learners have disparity towards their school teachers.

Through this study, it was evident that the steps that were taken to enhance the productive and receptive skills of the students haven't been much advantageous. The government has taken steps in providing qualified special teachers for the government schools to teach ESL. The prevailing system in schools and lack of enough time to engage in creative activities such as group works, debates, prompt speeches have paved the way to the downfall of the new strategies of ESL teaching. Those well-trained teachers become reluctant in the school sector and as a result, they implement those strategies during private tuition.

The government has taken steps to develop the ESL language, also through the distribution of textbooks but due to the shortage of time and other extra-curricular activities in the school system, the teacher is in a rush to complete the syllabus. Therefore, the students do have a negative perception towards the learning approaches of their school ESL teacher.

The negative attitudes towards tutoring were also taken into consideration. According to the students' idea, it was due to the large class tutoring and the attention paid by the ESL tutor is less.

The majority had a positive attitude towards the strategies of the private tutor than to their school ESL teacher.

\section{Significance of the study}

While results of the students' survey cannot be generalized to all the educational institutes, this study will provide valuable information regarding the perception of the students regarding the varying teaching strategies used by Government ESL teachers and private tutors in a particular mixed school in Galle District. Results will hopefully motivate other university students to investigate the various strategies used by the teacher and how it helps to develop the English Language proficiency of the learners. The results also may encourage the school administration to make necessary amendments to develop the teaching strategies and to motivate the teachers for a better outcome.

\section{Limitations}

In this research, the researchers have focused only on a sample set of 172 grade nine students in a particular school in the Galle District. One government school was selected due to the time factor and other practical issues. Due to the prevailed situation in the country, there were difficulties in drawing a comparison among the number of private tutors. There were issues related to data collection as some participants were reluctant to provide $100 \%$ authentic information. The perception of the students regarding their teachers were influenced by the parents of the students.

\section{Recommendations}

The research findings and revelation of the elements related to the phenomenon have provided feasibility to generate recommendations to develop the competence of the learners.

The study suggests that the school ESL teachers and the administration should pay special attention to the learner perceptions. The students are considered to be the most important group in the teaching-learning process. Therefore, 
the perception of the students towards the teaching approaches is very important.

- The school can observe the strategies used by the ESL teacher.

- Conducting an island-wide survey to identify the teaching approaches that students find effective in the process of learning ESL.

- Designing the textbooks to meet good strategies to teach the language.

- Inclusion of materials with practical purposes to make the learner motivated.

- Providing the freedom to the students to select good teaching approaches on behalf of the teacher to create a conducive learning environment.

The aforesaid recommendations are presented with the view of creating a good perception of the students regarding their school ESL teacher. It is because all the students are not privileged to attend private tuition in order to develop their ESL learning. Therefore, developing a positive student perception by implementing better teaching approaches to school ESL teachers can help all the students to be competent in English.

\section{REFERENCES}

Addisu, S. G \& Maria, P. (2020). Factors affecting the attitudes of students towards learning English as a foreign language, Cogent Education, 7:1, DOI: 10.1080/2331186X.2020.1738184

Bada, E. (1997). The model teacher: students vs. teachers. In A. Daloğlu \& Ü. VancıOsam (Eds.), 1st Inged-Metu International ELT conference proceedings: the role of collaboration in foreign language education. (pp.19-46). Ankara: Şafak Ltd.

Barkhuizen, G.P. (1998). Discovering learners' perceptions of ESL classroom teaching/learning activities in a South African context. Tesol Quarterly, 32 (1), 82-105

Bulut, T., \&Durak, S. (2002). The difference between the perceptions of the students and their teachers'. 1st International Symposium on Modern Approaches, Methods, \& ELT Problems, SDU, Isparta

Dawson, W. (2010). Private tutoring and mass schooling in East Asia: reflections of inequality in Japan, South Korea, and Cambodia. Asia Pacific Education Review, 11(1), 11-24

Hallac, J. \& Poisson, M. (2007). Corrupt Schools, Corrupt Universities: What can be done? Paris: IIEP-UNESCO. Retrieved from https://etico.iiep.unesco.org/sites/default/files/150259e.pdf

Lewis, M.\& Hill, J. (1990). Practical Techniques for language teaching (4th ed.). London: Commercial Colour Press.

Maithya, R. \&Mutua, E.K. (2015) Teacher and Students Perception on Effect of Extra Tuition on Academic Performance in Public Secondary Schools in Machakos County, Kenya. Journal of Educational Policy and Entrepreneurial Research (JEPER), 2(8). 57-66.

McDonough, S.H. (1986). Psychology in foreign language teaching. London: George Allen \& Hyman Ltd.

Samia, M. (2013). Reasons and necessity of Private tutoring in English for Bangla medium primary school students in Bangladesh, (Master's thesis, BRAC University, Dhaka, Bangladesh). Retrieved from http://core.ac.uk.net/61803067

Zhan, S; Bray, TM; Wang, D; Lykins, CR; Kwo, OWY (2013). The Effectiveness of private tutoring: Students' perception in comparison with mainstream schooling in Hong Kong. Asia Pacific Education Review, 14(4), 495-509. 